\title{
ОПТИМАЛЬНЫЙ ПОРЯДОК НАДЕЛЕНИЯ ПОЛНОМОЧИЯМИ ВЫСШЕГО ДОЛЖНОСТНОГО ЛИЦА СУБЪЕКТА РОССИЙСКОЙ ФЕДЕРАЦИИ В ПРЕДСТАВЛЕНИИ НАСЕЛЕНИЯ (НА ПРИМЕРЕ ЛИПЕЦКОЙ ОБЛАСТИ)
}

\author{
(c) 2019 Забайкалов Андрей Павлович
}

кандидат юридических наук, доцент, доцент кафедры «Конституционное и международное право» Липецкий филиал Российской академии народного хозяйства и государственной службы при Президенте Российской Федерации, Россия, Липецк

E-mail: zabaykalov@mail.ru

Совершенствование механизма наделения полномочиями высшего должностного лица субъекта Российской Федерации выступает одной из актуальных проблем современного конституционного права. Статья посвящена такому малоисследованному аспекту как выявление мнения населения по данному вопросу. В качестве основы использованы результаты опроса жителей Липецкой области. В результате констатируется, что не во всем позиция законодателей совпадает с мнением населения. Выводы исследования могут быть применены для дальнейшего совершенствования законодательства, прежде всего, избирательного.

Ключевые слова: возраст, выборы, выдвижение кандидатов, высшее должностное лицо, Липецкая область, самовыдвижение, срок полномочий, субъект Российской Федерации, ценз оседлости.

Федеральный закон от 06 октября 1999 года № 184-Ф3 «Об общих принципах организации законодательных (представительных) и исполнительных органов государственной власти субъектов Российской Федерации» [8, абз.2 ст.2] (далее - Федеральный закон от 06.10.1999 г. № 184-Ф3) предусматривает, что должность «высшее должностное лицо субъекта Российской Федерации» не является обязательной. Она только может устанавливаться высшими законодательными актами субъекта Российской Федерации (конституцией или уставом), но на практике является общераспространенной. Так, например, в соответствии с Уставом Липецкой области Российской Федерации от 9 апреля 2003 г. № 46-О3 [12, п.4 ст.39], администрацию области (постоянно действующий высший исполнительный орган государственной власти области) возглавляет глава администрации области - высшее должностное лицо области.

Должности высшего должностного лица субъекта Российской Федерации в нашей стране уделяется постоянное и пристальное со стороны не только представителей юридической науки, но и иных специалистов, а также граждан. И это вполне обоснованно. С одной стороны, широта круга полномочий, которые предоставляются высшему должностному лицу субъекта Российской Федерации, предопределяет его ключевую роль в региональной и даже федеральной политике. С другой стороны, как справедливо отметила И. О. Урусова, «статус высших должностных лиц субъектов Российской Федерации является квинтэссенцией проблем современного развития федерализма» [11, с.9].

Одной из основных проблем в данной сфере выступает выработка оптимального механизма определения лица, которое наделяется соответствующими полномочиями. Причем динамичность профильного законодательства свидетельствует о возможном промежуточном характере существующего порядка, что, с учетом относительной небольшого периода существования современной модели российского государства (если считать с 1993 года) и изменчивости современного мира, вполне допустимо и даже обосновано. А с учетом ч. 1 ст. 3 Конституции Российской Федерации [2] и того, что подотчетность и подчиненность органов публичной власти населению выступает составным элементом конституционных драйверов публичного управления Российской Федерации, т.е. конституционных точек развития публичного управления [13, с. 9], интересным представляется рассмотрение вопроса о том, как решение данной проблемы выглядит в представлении населения субъекта Российской Федерации.

Автором был проведен социологический

* Исследование выполнено при финансовой поддержке РФФИ в рамках научного проекта № 18-311-00351. 
опрос среди населения Липецкой области. Результаты опроса были подвергнуты стратифицированному отбору по нескольким признакам: пол, возраст респондентов (от 18 лет) и место проживания (муниципальные районы и городские округа).

Так, перед респондентами был поставлен вопрос: «Как следует наделять полномочиями главу администрации Липецкой области?». При этом предлагалось 3 варианта ответа: выборы населением, выборы депутатами представительного органа (Липецким областным Советом депутатов) и назначение Президентом Российской Федерации. Также респонденты могли предложить свой вариант ответа.

В результате подавляющее большинство (83\%) выбрало вариант «выборы населением». $10 \%$ опрошенных высказались за вариант «назначение Президентом Российской Федерации». 6\% отдали предпочтение варианту «выборы депутатами представительного органа (Липецким областным Советом депутатов)». Было также высказано несколько собственных вариантов. Однако, они не являются достаточно корректными, например, «назначение человеком-пауком».

Действующее федеральное законодательство [8, ст.18] устанавливает два способа определения человека для наделения его полномочиями высшего должностного лица субъекта Российской Федерации: выборы населением соответствующего субъекта Российской Федерации или выборы депутатами законодательного (представительного) органа государственной власти соответствующего субъекта Российской Федерации. Выбор между ними осуществляет субъект Российской Федерации самостоятельно. Липецкая область, как и большинство других субъектов Российской Федерации, пошла по пути установления выборов высшего должностного лица региона населением: «глава администрации области избирается гражданами Российской Федерации, проживающими на территории области ..., на основе всеобщего равного и прямого избирательного права при тайном голосовании» [12, п. 1 ст. 40].

Таким образом, позиция законодателей по данному аспекту совпадает с мнением населения Липецкой области.

Также перед респондентами был поставлен вопрос: «Каков оптимальный срок полномочий главы администрации Липецкой области?». При этом варианты ответа не предлагались.
В результате самым популярным (49\%) вариантом стал ответ «5 лет». Среди других распространенных вариантов ответа: 4 года $-24 \%, 3$ года $-11 \%, 6$ лет $-8 \%, 2$ года $-4 \%$. При этом нашлись как сторонники ежегодных выборов главы администрации, так и проведения их раз в 10 лет и реже.

В соответствии с федеральным законодательством [8, п. 5 ст. 18], срок полномочий высшего должностного лица субъекта Российской Федерации определяется конституцией (уставом) субъекта Российской Федерации, но не более 5 лет. В Липецкой области «глава администрации области избирается сроком на 5 лет» $[12$, п. 3 ст. 40]. При этом следует отметить, что аналогичный срок полномочий установлен во всех субъектах Российской Федерации.

Таким образом, позиция законодателей по данному аспекту совпадает с мнением населения Липецкой области.

Перед респондентами были поставлены вопросы о возрасте (возрастном цензе) главы администрации Липецкой области: «Каков должен быть минимальный возраст главы администрации Липецкой области?» и «Каков должен быть максимальный возраст главы администрации Липецкой области?». При этом варианты ответа не предлагались. Однако во втором случае был допущен ответ «Такой возраст устанавливать не нужно».

В результате при ответе на вопрос о минимальном возрасте большинство (34\%) выбрало вариант 35 лет. Однако вариант 30 лет поддержало не намного меньше респондентов - $28 \%$. По 19\% высказались за варианты 25 и 40 лет.

Также отсутствует четко выраженное мнение о максимальном возрасте возможного главы администрации Липецкой области. Большинство респондентов назвало вариант 65 лет. Однако речь идет о большинстве в $25 \%$. Данный срок, видимо, обусловлен ассоциациями с новым пенсионным возрастом (сроком выхода на страховую пенсию по старости) [7, ч. 1 ст. 8] и предельным возрастом пребывания на гражданской службе [4, ч. 1 ст. 25.1]. Вариант 60 лет обозначило $23 \%$ опрошенных. 16\% высказались за ответ 55 лет, а 9\% - 50 лет. При этом вариант «Такой возраст устанавливать не нужно» выбрали также 9\% опрошенных.

На федеральном уровне закреплено требование о достижении лицом, претендующим на пост высшего должностного лица субъекта 
Российской Федерации, возраста 30 лет [8, абз. 2 п.3 ст. 18]. При этом субъекты Российской Федерации не могут увеличивать или уменьшать этот возраст. Соответственно, аналогичный срок установлен в Липецкой области [12, п. 2 ст. 40].

Максимальный возраст ни федеральным законодательством, ни законодательством Липецкой области не предусмотрен.

Таким образом, позиция законодателей по данному вопросу расходится с мнением населения Липецкой области. Если действующее законодательство предполагает установление возрастных рамок для главы администрации Липецкой области от 30 лет без определения предельного возраста, то опрошенные представляют оптимальным поднять минимальный возраст кандидатов до 35 лет, а также установить максимальный возраст нахождения на данной должности в 65 лет. Причем на уровне субъекта Российской Федерации устранить данное противоречие невозможно.

Можно отметить, что среди действующих высших должностных лиц субъектов Российской Федерации только 3 не достигли 35 лет: А.А.Алиханов 1986 года рождения (Губернатор Калининградской области), Д.А.Артюхов 1988 года рождения (губернатор Ямало-Ненецкого автономного округа) и В. О. Коновалов 1987 года рождения (Глава Республики Хакасия - Председатель Правительства Республики Хакасия). Также 4 главы региона старше 65 лет или близки к данному возрасту: В.А. Васильев 1949 года рождения (Глава Республики Дагестан), В.Д. Волков 1954 года рождения (Глава Республики Мордовия), Е.С.Савченко 1950 года рождения (Губернатор Белгородской области), А.В.Усс 1954 года рождения (Губернатор Красноярского края). То есть расхождение не является существенным в масштабах страны.

Перед респондентами был поставлен вопрос: «Следует ли устанавливать срок, в течение которого кандидат на должность главы администрации Липецкой области должен прожить на территории Липецкой области («ценз оседлости»)?».

В результате подавляющее большинство (73\%) поддержало введение ценза оседлости, 18\% высказались против данного требования, а 9\% затруднились ответить.

При этом на вопрос «Если устанавливать срок «ценз оседлости», то какой продолжительности (в годах)?», наибольшей популярностью пользовались ответы 5 лет (34\%) и 10 лет (21\%). Варианты 1-3 года в совокупности нашли поддержку у $26 \%$ опрошенных. Встречалось и позиция о необходимости проживания в соответствующем регионе в течение всей жизни. Хотя, с другой стороны, около 3\% респондентов, несмотря на формулировку вопроса, настаивали на том, что ценз оседлости вводить не стоит.

Федеральный закон от 12 июня 2002 № 67Ф3 «Об основных гарантиях избирательных прав и права на участие в референдуме граждан Российской Федерации» [9, п. 5 ст. 4] с учетом норм Конституции Российской Федерации прямо запрещает введение ценза оседлости на выборах всех уровней и видов, кроме выборов Президента Российской Федерации. Таким образом, нормы, предусматривающие ценз оседлости, не могут присутствовать в законодательстве субъектов Российской Федерации. Более того, на выборах высшего должностного лица субъекта Российской Федерации довольно распространена практика поддержки федеральным центром кандидатов, ранее не связанных с соответствующим регионом. В частности, И.Г.Артамонов, до назначения его временно исполняющим обязанности главы администрации Липецкой области после досрочной отставки О.П.Королева в октябре 2018 года [5], не имел опыта жизни или работы в Липецкой области. Однако это не помешало ему набрать немногим более 67\% голосов избирателей и победить уже в первом туре выборов главы администрации Липецкой области, состоявшихся в сентябре 2019 года [6].

Таким образом, позиция законодателей по данному вопросу расходится с мнением населения Липецкой области. Если действующее законодательство предполагает прямой запрет на установление ценза оседлости для кандидатов на пост главы администрации Липецкой области, то опрошенные представляют оптимальным введение ценза оседлости и его установление на уровне 5 лет.

Следует признать, что вопрос об установлении ценза оседлости, в целом, является дискуссионным. Высказываются как доводы в поддержку этой идеи, так и аргументы против подобного ограничения пассивного избирательного права [1, с.149-150].

Перед респондентами был поставлен вопрос: «Как должно происходить выдвижение кандидатов на должность главы администрации Липецкой области?». Предлагалось 2 варианта 
ответа: самовыдвижение и выдвижение политическими партиями. Также респонденты могли предложить свой вариант ответа. При этом допускался выбор нескольких вариантов ответа.

В результате подавляющее большинство (86\%) поддержало применение самовыдвижения. Впрочем, выдвижение политическими партиями указала как возможный вариант также довольно значительная часть респондентов 57\%. Также высказывались предложения о предоставлении права выдвижения кандидатов на должность главы администрации Липецкой области общественным объединениям и иным организациям («предприятиям»).

Федеральное законодательство [8, абз. 3 п.3 ст. 18; 9, п. 2 ст. 32] закрепило в качестве приоритетного механизма выдвижения кандидатов на пост высшего должностного лица субъекта Российской Федерации выдвижение политическими партиями. Именно данный способ действует в обязательном порядке и «по умолчанию» считается единственным. Самовыдвижение установлено этой же нормой. Однако оно имеет факультативный характер и может дополнять выдвижение политическими партиями, если такое решение будет принято на уровне субъекта Российской Федерации и оформлено соответствующим региональным законом.

В Липецкой области только политические партии обладают правом выдвигать кандидатов на должность главы администрации Липецкой области [3, п. 1 ст. 26]. Что касается самовыдвижения, то оно не предусмотрено.

Таким образом, позиция законодателей по данному вопросу расходится с мнением населения Липецкой области. Если действующее законодательство не допускает самовыдвижение кандидатов на пост главы администрации Липецкой области, то опрошенные представляют оптимальным введение института самовыдвижения и даже поддерживают его в большей степени, чем выдвижение политическими партиями. Причем это противоречие существует и может быть устранено на уровне Липецкой области.

Следует отметить, что отсутствие в избирательном законодательстве субъекта Российской Федерации права на самовыдвижение на должность высшего должностного лица субъекта Российской Федерации проверялось Конституционным Судом Российской Федерации. В своем определении от 14 января 2014 года № 7-О [10] он указал, что само по себе отсутствие такого права не может быть признано препятствующим «эффективной реализации» гражданами пассивного избирательного права на соответствующих выборах. И, действительно, право политических партий выдвигать в качестве кандидата, как своего члена, так и лицо, не являющегося членом партии, в сочетании с широким спектром зарегистрированных в Российской Федерации партий, позволяет утверждать, что практически любое заинтересованное лицо, обладающие политическим весом, может получить поддержку той или иной партии. Так, среди действующих высших должностных лиц субъектов Российской Федерации имеются как самовыдвиженцы (например, А.Г.Дюмин, А. М. Осипов, В.И.Лимаренко и т.д.), так и беспартийные кандидаты, выдвинутые политическими партиями (например, В.В. Воскресенский, А.А.Евстифеев, С. К. Ситников и т.д.).

В итоге можно отметить, что не по всем рассмотренным аспектам позиция законодателей совпадает с мнением населения Липецкой области. При этом расхождение в представлениях не носит критический характер. В ряде случаев противоречия имеются именно с нормами федерального законодательства, что подразумевает низкую вероятность их устранения. Однако представляется, что корректировка регионального законодательства с учетом вышеизложенных положений могла бы повысить уровень конкуренции в политической сфере, степень интереса к выборам и избирательным кампаниям.

\section{Библиографический список}

1. Забайкалов А.П. О цензе оседлости при выборах высшего должностного лица (руководителя высшего органа исполнительной власти) субъекта Российской Федерации // Вестник Российского нового университета. Серия: Человек и общество. 2019. № 1.- С. 147-153.

2. Конституция Российской Федерации: принята всенародным голосованием 12 декабря 1993 г. // Собрание законодательства Российской Федерации. 2014. № 31. Ст. 4398.

3. о выборах главы администрации Липецкой области: закон Липецкой области от 09 июня 2012 г. № 45 -О3 // Липецкая газета. 2012. 20 июня. 
4. О государственной гражданской службе Российской Федерации: федеральный закон от 27 июля 2004 г. № 79-Ф3 // Собрание законодательства Российской Федерации. 2004. № 31. Ст. 3215.

5. О досрочном прекращении полномочий главы администрации Липецкой области: указ Президента Российской Федерации от 02 октября 2018 г. № 563 // Собрание законодательства Российской Федерации. 2018. № 41. Ст. 6229.

6. О результатах выборов главы администрации Липецкой области: постановление Избирательной комиссии Липецкой области от 10 сентября 2019 года № 94/798-6 // Липецкая газета. 2019. 11 сентября.

7. О страховых пенсиях: федеральный закон от 28 декабря 2013 г. № 400-Ф3 // Российская газета. 2013. 31 декабря.

8. Об общих принципах организации законодательных (представительных) и исполнительных органов государственной власти субъектов Российской Федерации: федеральный закон от 06 октября 1999 г. № 184-Ф3 // Собрание законодательства Российской Федерации. 1999. № 42. Ст. 5005.

9. Об основных гарантиях избирательных прав и права на участие в референдуме граждан Российской Федерации: федеральный закон от 12 июня 2002 г. № 67-Ф3 // Собрание законодательства Российской Федерации. 2002. № 24. Ст. 2253.

10. Об отказе в принятии к рассмотрению жалобы гражданина Иванова Вячеслава Константиновича на нарушение его конституционных прав положениями Закона Новгородской области «О выборах Губернатора Новгородской области»: определение Конституционного Суда Российской Федерации от 14 января 2014 г. № 7-О // Вестник Конституционного Суда Российской Федерации. 2014. № 4.

11. Урусова И. О. Конституционно-правовой статус высших должностных лиц субъектов Российской Федерации и их роль в системе федеральных и региональных органов власти: автореф. дис.. канд. юрид. наук. М, 2014. -22 c.

12. Устав Липецкой области Российской Федерации от 9 апреля 2003 г. № 46-О3: принят постановлением Липецкого областного Совета депутатов от 27 марта 2003 г. № 222-пс // Липецкая газета. 2003. 17 апреля.

13. Шукина Т.В.Классификация драйверов современного публичного управления // Вопросы экономики и права. 2018. № 122.- С. 7-10. 